\title{
On the Characteristics of Modern Education and the Connotation of Educational Informatization
}

\author{
Yan $\mathrm{Li}^{1, \mathrm{a},{ }^{*}}$ and $\mathrm{Yue} \mathrm{Wu}^{2, \mathrm{~b}}$ \\ ${ }^{1}$ Shaanxi Radio and TV University, Xi`an, Shaanxi, 710119, Chin \\ ${ }^{2}$ Xi'an University of Technology, Xi'an, Shannxi, 710048, China \\ ${ }^{*}$ Corresponding author.Email: ${ }^{a}$ Email:19964262@qq.com, ${ }^{b}$ Email:1319606102@qq.com
}

\begin{abstract}
With the development of the society and the changes of the times, the modern education comparing to traditional education presents many new features, the connotation of the education information is also increasingly rich, which driving people to understand the modern education deeply. At first, this paper expounds the three major characteristics of modern education: the globalization of education target, education of infinite time and space, the democratization of education process. Then from the information infrastructure, education, scientific research and the quality of people, it grasps the three aspects of the connotation of education informatization; Finally on its basis, combining the deficiencies in the process of modern education information, and putting forward three feasible development methods, namely to shrink the gap of the different types of higher education informatization construction ,to increase the balance of regional informatization development; Strengthen the operation mode of the standard information management system of higher education, and establish education idea corresponding to information age; Increase the investment of higher education informatization construction, and pay attention to investment costs and accounting about benefit.
\end{abstract}

Keywords: Modern education, Educational information, Characteristic, Intension, Method.

\section{INTRODUCTION}

The main purpose of modern education is to cultivate the people needed in modern society. The pace of social modernization has accelerated, and modern education has presented a variety of characteristics. This mainly includes the globalization of educational goals, the limitlessness of educational time and space, and the democratization of the educational process. In the ever-changing era of the 21 st century, exploring and analyzing the characteristics of modern education can help us better understand the trend of modern education in educational informatization. In recent years, educational informatization in various countries has been advancing in a competitive manner. Those who can go deep into educational informatization at a speed of thousands of miles a day and stand on the front stage of the development of "educational informatization" can seize the opportunity, strengthen their own economic capacity and grasp the right to speak in the forest of the world's nationalities. Just because of the charm of educational informatization, all countries are actively exploring on the way of educational informatization, investing a lot of manpower and material resources to forge ahead courageously. China is no exception, and attaches great importance to the construction of higher education information.

\section{THE CHARACTERISTICS OF MODERN EDUCATION}

On the understanding of modern education, it is also "the benevolent sees benevolence, the wise sees wisdom." We generally believe that modern education must first be "modern" in time. In other words, modern education refers to education that is compatible with modern production systems and cultural systems. Therefore, it also always changes with the changes of the social environment and the human environment. In these changes, it will inevitably show a series of characteristics different from the previous era. 


\subsection{Globalization of Educational Goals}

The goal of education is to cultivate the direction and specification of people, that is to say, what kind of talents should be cultivated. The current era is an open era, and the talents cultivated now will step out of regional boundaries and face the world. The globalization of educational goals is mainly embodied in quality education, general education, creative education and personality education. The first is quality education. The opposite of quality education is examination-oriented education. Examination-oriented education takes the enrollment rate as the only educational goal and ignores the educational law; The main purpose of quality education is to enable students to obtain physical and mental development, in line with the law of education. The second is general education. The opposite of general education is specialist education. By broadening students' knowledge, general education enables students to involve in different fields, so that the cultivated talents have strong social adaptability. The third is creative education. Creative education can make students more vigorous and better promote social progress. The fourth is personality education. Personality education is to cultivate people with uniqueness, freedom and independence.

\subsection{Limitlessness of Educational Time and Space}

In modern society, in terms of time, people's education is no longer limited to the period from birth to employment, but advocates lifelong education; In terms of space, education is no longer limited to schools, but more and more advocates that education can be received in the family and society, which is the idea of lifelong education. In fact, this kind of educational thought was put forward by Paul Langer, a famous expert of adult education in France, as early as 1965. During the International Conference on the Promotion of Adult Education held under the auspices of UNESCO, it was identified as an important educational thought, which has a great and far-reaching impact on the whole world. The idea of lifelong education is universal, and all people can receive education; Lifelong education is extensive, including family education, school education and social education; The biggest feature of lifelong education is lifelong ness. It can be used flexibly at anytime and anywhere to promote the cultivation of talents.

\subsection{Democratization of the Educational Process}

Educational goals change with the times, so the corresponding educational process will also change. Nowadays, the educational process is more democratic than the traditional one, which is mainly reflected in the following aspects. Firstly, the relationship between teachers and students or the status of teachers and students has changed. In ancient education, the status of students and teachers is not equal, teachers are in an absolute dominant position, in which teachers impart knowledge, and students accept knowledge. However, modern education emphasizes the main position of students and the initiative of students to study and seek knowledge. Then the teacher will give proper guidance. The present class emphasizes the interaction between teachers and students, students at present have more voices than in the past, and teachers and students are equal. Secondly, educational channels have become more open Traditionally, students are educated in the classroom, but now education is not confined to the classroom. Students can either go out of the classroom or stay at home and use news multimedia to learn knowledge and receive education in the online courses.

\section{THE CONNOTATION OF EDUCATIONAL INFORMATIZATION}

The so-called educational informatization is a process in which teachers and students of education use information technology to promote educational reform and development on the basis of network environment, so as to realize the modernization of education and meet the needs of the times and society. This process inevitably involves such elements as educational infrastructure, educational research and human quality.

\subsection{The Construction Level of Information Infrastructure is the Foundation of Educational Informatization}

The realization of educational informatization needs a certain material foundation, so it is necessary to carry out information infrastructure construction continuously. If the information infrastructure is well constructed, the level of educational informatization will be improved accordingly; If the construction of information infrastructure is deficient, then educational informatization is "empty talk". As early as the 1970s, some advanced European countries have begun to introduce a series of planning measures to improve infrastructure construction. In 1993, the United States also issued the construction plan of "national information infrastructure" and "information superhighway". In recent years, Chinese government has also attached great importance to the construction of infrastructure in the process of promoting informatization of higher education, issued various documents for policy support, improved the construction of information infrastructure continuously, and achieved good results in informatization of higher education. 


\subsection{Educational Scientific Research is one of the Main Tasks of Educational Informatization}

In colleges and universities, the most important index to measure the teaching quality of a school is its teaching quality and scientific research achievements. Teachers not only bear the heavy burden of teaching and educating people, but also should devote themselves to educational scientific research which is one of the main tasks of educational informatization. Educational informatization needs huge input of manpower, material and financial resources. If educational scientific research can achieve better results and apply these results to education and teaching, then we can make the information infrastructure to be used more efficiently and information resources more widely shared. Therefore, while devoting themselves to educational scientific research, teachers should focus on how to use information technology to teach and improve the quality of teaching.

\subsection{The Quality of People is the Key to the Success of Educational Informatization}

In modern education, we always emphasize on improving people's quality. For educational informatization, the quality of people is the key to their success and failure, and the quality of teachers is the key. Faced with information resources like mountains and seas, these resources inevitably have advantages and disadvantages. However, students with less experience may not have clear ability to distinguish, which requires teachers to select for students in advance and present the best information resources to students. Therefore, teachers should constantly improve their information quality. Schools should also provide appropriate training for teachers so that they can have access to the latest and most complete information resources, so as to better improve their own quality, improve the quality of students, and speed up the process of informatization in colleges and universities.

\section{THE PATH OF HIGHER EDUCATION INFORMATIZATION CONSTRUCTION IN CHINA}

As can be seen from the above analysis, China's modern education presents the characteristics of diversification, and the connotation of higher education informatization is also increasingly rich. However, there are still many problems in the process of higher education informatization. For example, the development of higher education informatization among regions is not balanced, there is no unified standard for planning and management, and the investment is not sufficient. In view of these problems, this paper proposes the following three corresponding measures.

\subsection{Narrowing the Gap between Different Types of Higher Education Informatization Construction, Increasing the Balance of Informatization Development among Regions}

On the one hand, we should narrow the gap between different types of higher education informatization construction. There are different types of universities in China, such as adult universities, private universities, ordinary universities and so on and there are great differences in information construction among them. In view of this problem, we should aim at the target and adopt the following development strategies.

Firstly, the informatization construction of adult universities is far behind that of ordinary universities and private universities, so the informatization construction of adult universities should be paid special attention. In adult universities, there may not be a more rigorous teaching system as in ordinary universities. Generally speaking, the teaching of adult universities is more flexible and free, so it is more necessary to improve the informatization level of this kind of schools. Adult universities should provide more electronic books for students, it is better to equip students with a special reader, so that they can read professional books anytime and anywhere; In the computer room, the number of computers should be increased so that every adult student can enjoy modern educational resources. Moreover, for aging computers, we should constantly update to ensure the timeliness of information acquisition; The number of seats should be increased in voice classrooms and multimedia classrooms; We should popularize online course teaching, increase the number of courses and improve the quality of courses. In a word, the informatization development level of adult universities should be improved from many aspects, so as to narrow the gap with the informatization construction of private universities and ordinary universities.

Secondly, in addition to allowing students to have more e-books, more computers, enough voice classroom seats, more multimedia classroom seats, private universities should also popularize campus network in school classrooms, dormitories, restaurants, so that students can access the latest information at anytime and anywhere, so as to constantly update their knowledge reserves.

Thirdly, general universities should also improve students' general book ownership and the number of online courses as soon as possible, and constantly develop online quality courses, so as to improve the information level and try to catch up with developed countries. On the other hand, we should increase the balance of information development among regions. China is a country with unbalanced economic, political and cultural development. The eastern part of the country is developing rapidly, while the central and western regions are lagging behind. 
The development of higher education informatization should not blindly seek new skills and new technologies, but should take different strategies according to their own local economy and different educational and cultural needs. For example, the central and western regions need to improve the construction of informatization infrastructure, and the state should provide policy support, encourage more education talents from the central and eastern regions to work in the west, and provide special funds for the central and western universities to try to keep up with the pace of informatization in the east; The informatization level of higher education in eastern China is relatively high, but there is still a considerable gap with developed countries. The eastern part of China should continue to strengthen the construction of infrastructure and hardware facilities, as well as software development, so as to carry out distance education, share educational resources and strive to narrow the gap with developed countries.

\subsection{Strengthening the Standardization of the Operation Mode of Informatization Management in Higher Education, Establishing an Educational Concept Compatible with the Informatization Age}

On the one hand, we should strengthen the standardization of the operation mode of the informatization management in higher education. The standardization of the operation mode of higher education informatization management mainly refers to the following aspects in the process of higher education informatization, including strong leadership, all-round planning, step-by-step organization and appropriate control, etc. The management and operation mode of higher education informatization is various. Because of the variety of management methods, it may also be more random, resulting in management chaos. The efficiency of higher education informatization is not high, so it is urgent to strengthen the standardization of the operation mode of higher education informatization management. The specific rules are as follows:

Firstly, in terms of the leadership mode of higher education informatization, we should select a group of management talents in higher education informatization, conduct some professional training for these talents, and constantly coordinate various factors and conditions in the higher education informatization system. It is also necessary to establish and improve the guarantee system of various educational informatization, promote the sharing and reuse of advantageous information resources, and strive for the realization of unlimited value of limited resources.

Secondly, in terms of organizational setup of higher education informatization, we should not repeat the establishment of educational informatization institutions with the same functions. On the contrary, we should follow the principle of streamlining, and set different and specific management objectives in the organizational structure, with a clear division of labor and mutual coordination, so as to continuously improve the efficiency of management.

Thirdly, in the control and management of higher education informatization, this mainly means that in the process of higher education informatization, teaching quality should keep pace with its development speed. In the areas of learning, cultivating talents, and developing society, we must take all these into consideration. Moreover, we should establish corresponding management evaluation system, so as to supervise the control and management of higher education informatization reasonably, clarify the gains and losses, correct the mistakes, and praise the advantages, to ensure the accuracy of human, material and financial input and improve the management efficiency.

Fourthly, the time management of higher education informatization: Efficient management talents must know how to reasonably grasp the time, to know how to divide the time into small units, and compare the efficiency of educational informatization within these units. Or, they must be able to determine some relatively fixed time to check the work in the process of educational informatization, so as to timely feedback the problems in the work and make continuous improvement, and so as to better promote the process of educational informatization.

On the other hand, we should set up educational concepts suitable for the informatization age. In today's society, education plays a leading role in all aspects of society, and the development of society must rely on education. As the saying goes, "Hand is the thought of the brain", what kind of thought will be what kind of behavior; What kind of educational concept will be what kind of educational behavior. With regard to educational concepts, the following should be done: First of all, we should constantly update the educational concept of the leaders of higher education, so that they can set up the educational concept that meets the requirements of the times, abandon the backward and outdated educational concept, so as to keep up with the pace of educational informatization; Secondly, we should construct teachers' information values, actively train new teachers to use advanced equipment technology, so that each teacher can skillfully use multimedia equipment in the teaching process, and improve the teaching effect by using massive information resources and various information means; Finally, we should change the concept of staff, open informatization courses for students, let students also establish informatization $\mathrm{n}$ awareness, have informatization vision, and ensure a high degree of social adaptability to the modern information society. 


\subsection{Increasing Investment in Higher Education Informatization Construction, Paying Attention to the Accounting of Investment Cost and Utilization Efficiency}

On the one hand, it is necessary to increase the investment in the construction of higher education informatization. The so-called economic foundation determines the superstructure, and the economic level also determines the level of informatization construction of higher education. China is an underdeveloped country and its economy is still relatively backward. Many colleges and universities are short of funds, their teaching hardware equipment is backward. They have no money for software development, and the level of education informatization is backward. In view of these problems, we must take some necessary measures.

Firstly, the state should increase financial input to ensure that colleges and universities have a better economic foundation, so that they have the financial resources to carry out a certain level of information infrastructure construction;

Secondly, the government must introduce corresponding policies, adopt some necessary social measures, carry out various fund-raising and financing, and accelerate the construction of informatization infrastructure in higher education through various forces;

Thirdly, colleges and universities should make full use of some of the better resources they have. For example, in the field of information science, we can encourage teachers to study more, provide certain financial support and welfare policies, and gradually transform these talents and resources into informatization technology achievements. In turn, these achievements can be recycled repeatedly, so that the informatization of higher education mainly depends on its own strength for long-term progress.

On the other hand, for the cost of investment and utilization efficiency, it needs timely accounting.

Higher education informatization is not only the need of social development, but also the need of the development of higher education itself. Therefore, school leaders should attach great importance to it and take corresponding measures. Firstly, in the overall planning and development of schools, the informatization construction of higher education should be incorporated into the planning system as an important part. Only when the informatization construction is brought into the system can colleges and universities treat it as an urgent task; Secondly, schools should set up decision-making institutions for informatization leadership. These institutions should be led by school leaders with advanced educational concepts, and their informatization construction should be strictly standardized, reasonably organized and effectively coordinated; Thirdly, according to the actual situation of schools, we should determine the specific needs and objectives of informatization construction, and formulate unique development plans of education informatization. On the basis of setting clear objectives, setting reasonable demands, establishing sound decision-making institutions and cultivating professional management talents, the investment costs and utilization efficiency are constantly calculated. We should strive to make "good use of steel in the blade", spend a penny and get a benefit, gradually make the budget and investment mode tend to be economical, and bring the limited funds of university informatization construction into full play.

\section{CONCLUSION}

In a word, the society is in constant change, and education is changing with it. In addition to the globalization of educational goals, the limitlessness of educational time and space, and the democratization of educational process, there are other characteristics of modern education, such as the advancement of educational status, the class of education and so on. Along with these characteristics, it comes the informatization of education, which has become an inevitable trend. We should grasp this trend, dare to try, dare to innovate, and constantly explore the correct path to promote educational informatization.

We believe that as long as we keep moving forward, we will surely promote the rapid development of university informatization, cultivate highly effective talents beneficial to the society, and jointly promote the overall progress and healthy development of the society.

\section{REFERENCES}

[1] Yang Kaicheng, Xu Yi. On the Basic Features of Modern Education and the Deep Connotation of Educational Informatization[J]. Journal of Electronic Education Research, 2016 (01): 12-24.

[2] Zhang Lele. On the Connotation and Characteristics of Modern Vocational Education System[J]. Theory and Practice of Education, 2013 (33): 26-28.

[3] Zheng Xudong, Wei Zhihui. The Trends of Information Technology in Higher Education: An Interview with President of EDUCAUSE, Dr. Diana Oblinger [J]. Open Education Research, 2014 (06): 4-9.

[4] Zheng Xudong, Yang Jiumin. The Trends of It in Higher Education and the Future of Collegiate Teaching and Learning Innovation Implication from the 2014 EDUCAUSE Top Ten Issues[J]. China Educational Technology, 2014 (331): 31-42. 
[5] Yao Lining, Wang Yuchuan, Chen Xiaoping, Lu Hongzhang. Promoting the Reform and Innovation of Education and Teaching with the Construction of Higher Education Informatization[J]. Education Forum, 2016 (19): 95-96.

[6] Wang Qi, Qin Jin. Research on Effective Application of Educational Resources in Higher Education Informatization Construction [J]. Software Guide (Educational Technology), 2015 (9): 48-49.
[7] Zhao Yanyan. Higher Education Services Targeted at Information Technology Inquiry [J]. Computer Knowledge and Technology, 2013 (9): 50-52. 